\title{
Trainspotting'in Türkçe Çevirileri Işığında Heteroglossia Çevirisine Kitle-Tasarımı Odaklı Bir Yaklaşım ${ }^{1}$
}

\author{
An audience-design approach to the translation of heteroglossia: the case of \\ Trainspotting in Turkish
}

Araştırma/Research

\section{Hilal ERKAZANCI DURMUŞ*}

*Dr. Öğretim Üyesi, Hacettepe Üniversitesi, Edebiyat Fakültesi, Mütercim-Tercümanlık Bölümü, hilalerkazanci@yahoo.co.uk, ORCID ID: orcid.org/0000-0003-2790-0415

\section{ÖZET}

Biçemsel olarak dilin farklı katmanlaşma şekillerine işaret eden ve yazın metinlerinde ideolojik bir işleve sahip olan heteroglossia, okura belirli bir dünya görüşü ve kimlik sunar. Bu nedenle, heteroglot sesler, yazın metinlerinde bağlamın önemli bir parçası olarak karşımıza çıkar. Kaynak metindeki heteroglot sesler, çevirmeni ve okuru okuma sürecinde yönlendiren iletişimsel ve bağlamsal bir ipucu görevi üstlenir. Bu çalışmada, heteroglot seslerin bir metnin bağlamını nasıl değiştirebileceği sorusuna yanıt bulmak üzere bağıntı kuramı kullanılmaktadır. Heteroglot seslerin erek dile nasıl aktarılacağı konusu ise çevirinin yapıldığı hedef kitlenin kimlerden oluştuğu, çeviriye ilişkin beklentilerin ne olduğu ve dil düzeyinde kabul edilebilirlik normları gibi etkenlerle yakından ilişkilidir. Çevirmenler, erek dil okurunun beğenisini kazanmak ya da yapılan çevirinin toplumda kabul edilebilir bir çeviri olarak alımlanmasını sağlamak için - hedef kitleye özgü olduğu varsayılan özelliklere dayanarak- kaynak metnin biçemsel özelliklerinde bir takım değişiklikler yapabilmektedir. Bu bağlamda, çalışmada Irvine Welsh'in sosyo-biçemsel düzeyde farklı heteroglot sesleri ön plana çıkardığı Trainspotting adlı romanı ve bu romanın iki çevirisi incelenmektedir. Toplumdilbilimsel bir kavram olan kitle tasarımı kavramından yola çıkan bu çalışmada, bir yandan, heteroglot seslerin çevirisinin, dile ilişkin olarak toplumda var olan bakış açısı ve söylemlerden etkilendiği anlaşımakta; diğer yandan ise, bir toplumda heteroglot seslerin çevirisi için sistematik olarak tercih edilen stratejilerin, toplumun dil hakkındaki görüşlerine ve çevirmenlerin zihnindeki kitle tasarımına ışık tuttuğu sonucuna varılmaktadır.

Anahtar sözcükler: heteroglossia, çeviri, biçem, bağıntı kuramı, kitle tasarımı

\footnotetext{
${ }^{1}$ Bu çalışma East Anglia Üniversitesi'nde yürütülmüş olan Heteroglossia in Turkish translations: Locating the style of literary translation in an audience-design perspective (2006) başılıklı tez çalışmasından üretilmiştir.
} 


\section{ABSTRACT}

Literary heteroglossia refers to the textual representation of the division of a language into different varieties which differ from the norms of the standard language. Given its underlying ideological layers, heteroglossia forms a significant part of the context of a literary text. The heteroglot voices serve as ostensive-inferential clues which guide both the source-text reader and the translator in the reading process. Therefore, the study focuses on relevance theory in order to shed light on this process. The study also underlines that the translation of heteroglossia largely depends on the translator's consideration of a particular audience design. That is, the typological profile of readers and their perceived (socio)linguistic expectations coexist with translation. To illustrate this point, this study focuses on how various heteroglot voices in Irvine Welsh's Trainspotting are translated into Turkish. Ultimately, the study underlines, on the one hand, that it is possible to derive particular forms of translations from a posited audience design. On the other hand, the study highlights that the systematic choices made by the translators in a particular society can provide us with a particular audience design with respect to the translation of heteroglossia.

Key words: heteroglossia, translation, style, relevance theory, audience design

\section{Giriş}

Bu çalışmanın amacı, Mikhail Bakhtin'in (1981) heteroglossia kavramından yola çıkarak dil değişkelerinin yazın metinlerinde nasıl bir rol oynadığını incelemek ve heteroglot seslerin çeviri yoluyla aktarımı söz konusu olduğunda hedef kitlenin yazın geleneklerinin, dil normlarının ve dil üzerine oluşturduğu söylemlerinin çeviriyi nasıl etkileyebileceğine ışık tutmaktır. Heteroglot seslerin yazın metinlerinde bağlamsal bir ipucu olarak kullanıldığını göstermeyi hedefleyen bu çalışmada, Dan Sperber ve Deirdre Wilson'un (1986) bağıntı kuramı çerçevesinde, bu seslerin taşıdığı politik altmetnin biçemsel unsurlar yoluyla yazar tarafından okura nasıl ulaştırılabildiği gösterilecek ve söz konusu biçemsel özelliklerin çevirideki rolü üzerinde durulacaktır.

Çalışmada, ayrıca, Allan Bell'in (1984) kitle tasarımı kavramı kullanılarak erek metnin biçeminin, erek toplumda var olan birtakım yazın geleneklerinden, yazım kurallarından, belirli kanunlardan ve bunların ışığında ortaya çıkan söylemlerden hareketle çevirmenlerin zihinlerinde oluşturdukları kitle tasarımına bağı olarak şekillendirildiği gösterilecek ve bir toplumda çevirmenlerin sistematik olarak kullandığı çeviri stratejilerinin ve biçemsel düzeydeki tercihlerinin, o toplumda özgün metinlere ve çevirilere dair sosyo-biçemsel ve ideolojik beklentilere ışık tutabileceği görüşü vurgulanacaktır.

Yukarıda belirtilen amaçlar, İskoç bir yazar olan Irvine Welsh'in (1993) Trainspotting adlı romanı ve bu romanın iki Türkçe çevirisi özelinde ele alınacaktır. Çalışmada incelenecek olan çevirilerden ilki 2001 yılında Stüdyo İmge tarafından, ikincisi ise Siren Yayınları tarafından 2010 yılında yayımlanmıştır. Çalışma için Trainspotting'in seçilmesinin nedeni, romanda ön plana çıkan heteroglot seslerin ideolojik bir mesaj içermesi, bu mesajın biçemsel ipuçları (heteroglossia kullanımı) ile örtükleştirilmiş bir şekilde okura sunulması, heteroglot seslerin ortografik düzeyde metne aktarılması sürecinde aşırıya kaçılarak, kaynak metin okurunun, Talib'in ifadesiyle (2002, s. 33), "dil içi bir şiddet[e]" maruz bırakılması ve bazı tabu kelimelerin heteroglot seslerin ayrılmaz bir parçası hâline getirilmesi ile sosyo-biçemsel düzeyde oluşturulan 'şiddetin' daha da 
artırılmasının çeviri için birtakım zorlukları da beraberinde getirmesidir. Bu bağlamda, çalışmada, kaynak metinde örtükleştirilmiş olarak biçemsel düzeyde oluşturulan bağlamsal ipuçlarının erek metine nasıl aktarıldığı ve bu durumun nedenleri sorgulanacaktır.

\section{Kuramsal Çerçeve}

\subsection{Heteroglossia Nedir?}

Biçemsel olarak farklı dilsel katmanlaşma şekillerine işaret eden heteroglossia, Bakhtin'in (1981) polifoni (çok seslilik) kavramının bir parçasıdır. Bakhtin, yazınsal ürünlerin toplumsal düzeyde farklılık gösteren dil değişkelerinden oluştuğunu ve bu tür biçemsel özelliklerin yazın metinlerinde ideolojik bir işleve sahip olduğunu belirtmiştir (1981, s. 262). Edebiyatta biçem ve içeriğin bir bütün olarak var olduğu görüşünü vurgulayan Bakhtin, çalışmalarında biçemin sosyolojik işlevine dikkat çekmiştir (1981, s. 262). Dilin toplumsal süreçte katmanlaşmasına işaret eden heteroglossia kavramı lehçeler, mesleki jargonlar, yaş gruplarına özgü dil kullanımları, çeşitli gruplara özgü konuşma şekilleri gibi dilin katmanlaşan parçalarını ifade etmektedir. Bakhtin, yazın metinlerinin heteroglot dil kullanımı ile birlikte diyalojik bir yapı kazandığını belirtmektedir çünkü heteroglot sesler dilin "üniter", "tek", "tartışılmaz" ve "kutsanmış" yapısını tartışmaya açarak farklı bakış açılarına, farklı dünya görüşlerine ya da farklı bir toplumsal gerçekliğe vurgu yapmaktadır (1981, s. 262).

Heteroglossia, okura belirli bir dünya görüşü ve kimlik sunar çünkü yazın metninde üstlendiği görev ideolojik düşünce ekseninde birleştirici ve bütünleştirici bir işlev yüklenen dilin "düzgün” bir şekilde kullanılmasına gölge düşürmektedir (Bakhtin, 1981, s. 668; 2001, s. 270). Bakhtin'in heteroglot seslere ilişkin görüşleri, bu noktada, "meşru dil" kavramını ortaya atan Bourdieu ile kesişmektedir (1991, s. 53). Bourdieu'ye göre, "tüm dil pratikleri [toplumda] meşru [sayılan] pratiklere göre değerlendirilmektedir" (1991, s. 53). Ayrıca, bir toplumda belirli bir dil kullanımının (örneğin, ölçünlü dil) kabul görmesi, bu kullanımın hem "biçemsel düşünce" boyutunda içerik ve gücünü pekiştirir; hem de birçok yazın türünde "yaratıcı[lık]" sınırlarını çizme ve "biçemsel açıdan belirleyici" bir rol oynama olanağı verir (Bakhtin, 1981, s. 668). Bu nedenle, heteroglossia kullanımı sadece toplumda kabul gören yazın dilini hedef almakla kalmaz; aynı zamanda, bu yazın dilini kullanan ulusun dilsel ve ideolojik birliğini de hedef alır (Bakhtin, 2001, s. 272). Bu bakımdan, heteroglossia yazın metinlerinde çeşitli sezdirimlere neden olarak okura belirli mesajlar verebilir. Bu çalışmada, heteroglossia bu bağlamda ele alınacaktır.

\subsection{Bağıntı Kuramı Perspektifinden Heteroglossia}

Bağıntı kuramı, Sperber ve Wilson (1986) tarafından insanlar arasındaki bildirişime bilişsel-edimbilimsel bir pencereden bakan bir yaklaşım olarak ortaya atılmıştır. Sperber ve Wilson (1986, s. 33), Grice (1975) tarafından sıklıkla vurgulandığı şekliyle, konuşmacının ya da yazarın "niyeti" kavramından yola çıkarak, niyetin sezilmesinin dinleyici/okur tarafından çıkarımlarda bulunulmasına bağlı olduğunu ve bildirişimin bir tür çıkarım olduğunu belirtmiştir. Bildirişimin ilk aşaması 
konuşmacı/yazar tarafından üretilen sözcelerin dilsel bir uyarı olarak çözülmesi; ikinci aşama çıkarım aşaması ve üçüncü aşama ise sözcelerin altında yatan niyetin sezilmesidir (Sperber \& Wilson, 1986, s. 33).

Bağıntı kuramına yazın metinlerinin ışığında bakacak olursak, okur ne kadar bağlamsal etkiye ulaşırsa, metnin o kadar güçlü bir bağıntıya kavuştuğunu görürüz. Okur, yazın metninden sınırsız sayıda çıkarımda bulunabilir (MacKenzie, 2002, s. 25). Bildirişim, okurun sınırsız sayıda çıkarımı daraltabilmesi ve bilgiye ulaşması ile sağlanır (MacKenzie, 2002 , s. 25). Yazar iletmek istediklerini ya açık gönderimler ya da sezdirimler ile aktarır (Sperber \& Wilson, 1986, s. 15). Yazın metinlerinin en önemli özelliklerinden biri örtük bilgilerin (örneğin, biçemsel ipuçları ile verilen mesajlar) varlığıdır. Örtük bilgiler, metnin ve bağlamın temelinde çıkarımlara bağlı olarak anlam kazanmaktadır. Bu bakımdan, okurun sahip olduğu art alan bilgisi ve bağlam bir araya getirildiğinde bağıntı sağlanmış olur.

Bağıntı kuramının en önemli unsurlarından birisi bağlamdır. Bağlam, insan zihninin üretebileceği her türlü varsayımı kapsayabilir (Sperber \& Wilson, 1986, s. 15). Bağlam, okurun içinde bulunduğu toplumdan ya da daha önce okuduğu metinlerden elde edilen bilgi ile birlikte "dini inanışlar, anılar, kültürel yargılar, konuşmacının zihinsel durumuna ilişkin inanışlar[ı]" içerir (Sperber \& Wilson, 1986, s. 15).

Metinde bulunan her sözce bağıntı etkisi yaratabilir (Sperber ve Wilson 1986, s. 45). Bir metnin ya da metnin içindeki bir biçemsel unsurun bağlamsal bir etki oluşturması için bağlamın (i) okurun sahip olduğu eski bilgilerle metinden edindiği yeni bilgi arasında etkileşim kurması, (ii) okura ait bir varsayımı güçlendirmesi veya desteklemesi ya da (iii) okura ait varsayımları ortadan kaldırması veya okurun sahip olduğu eski bilgilerle çelişmesi gerekmektedir (Sperber \& Wilson, 1986, s. 108). Bağlamsal etki ne kadar güçlü ise, okur o kadar etkin bir bağıntı kurabilir. Bağıntı kuramı, bağlamsal etkiyi en az çabayla en üst düzeye çıkarmanın (maliyet/kâr ilişkisi) çok önemli olduğuna vurgu yapmaktadır (Sperber \& Wilson, 1986, s. 108); ancak bu durum yazın metinlerinde daha farklıdır. Yazın metinlerinde, biçemsel bir unsurun (örneğin, değişmeceli dil kullanımı, göndermeler, ölçünlü dilden farklı olan heteroglot sesler ve benzeri biçemsel özellikler) anlaşılması ne kadar zor olursa olsun, okurun metni anlamak için mümkün olduğunca çaba göstermesi ve en etkili bağıntıyı kurması gerekebilir (Boase-Beier, 2004, s. 280). Başka bir ifadeyle, yazın metninin okuru ne kadar çaba harcarsa, okuduğu metnin bilişsel getirisi de o ölçüde artabilir. Bilişsel getiri ne kadar artarsa, yazınsal metnin kazandıracağı okuma tecrübesi o ölçüde verimli olur (MacKenzie, 2002; Boase-Beier, 2004, s. 280). Örneğin, William Burroughs'un kolaj tekniği ile ürettiği metinleri okuyan bir okurun en az zihinsel çaba ile en üst düzeyde okuma zevkine ulaşmasını beklemek mümkün değildir. Aynı durum, heteroglot sesleri barındıran yazın metinleri için de geçerlidir.

Okurun biçemsel açıdan birtakım zorluklar içeren yazın metinlerini okuma sürecinde belirli çıkarımlarda bulunmasına olanak tanıyan nedir? Etkileşimsel toplumdilbilim çalışmalarına odaklanan Gumperz' in (1982) "bağlamsal ipuçları" kavramı, bu konuda hem çevirmene hem de okura yol gösterici olmaktadır. Yazar ile ortak bir bağlama sahip olmak için, çevirmen ve okur gözlem yaparak ulaştıkları ipuçları sayesinde belirli bir kaynak metne dair belirli çıkarımlarda bulunabilir. 
Bu konuyu bağıntı kuramı çerçevesinde çeviriyle ilişkilendiren ilk araştırmacı Gutt (1991) olmuştur. Gutt, bağıntı yönünden kaynak metne benzer bir yazın metni oluşturma amacını taşıyan bir çevirmenin, kaynak ve erek metinler arasında belirtikleştirme ve örtükleştirme açısından "yorumlayıcı" bir benzerlik oluşturması gerektiğini vurgulamaktadır (2000, s. 104). Diğer bir ifadeyle, kaynak ve erek metinler belirtiklik ve örtüklük bakımından ne kadar benzerlik gösterirse, kurulan bağıntı da o ölçüde birbirine benzer. Bağlamsal ipuçları sayesinde, çevirmen kaynak yazın metni ile erek metin arasında "yeterli bağıntı[yı]" kurabilir (Gutt, 1991, s. 55-56).

Özellikle biçemsel kaygıların ön planda olduğu yazın çevirisinde, örtük unsurların belirtikleştirilmesi veya belirtik unsurların örtükleştirilmesi kaynak metinde var olan bağlamsal ipuçlarının erek metin okuruna aktarılamamasına neden olabilir. Bu nedenle, yazarın kaynak metinde kurduğu bağıntı, erek metinde oluşturulamayabilir. Bu noktada, yazar terimi ile neyin kastedildiğini açığa kavuşturmak gerekmektedir. Bu çalışmada geçen yazar ifadesi, gerçek bir yazar yerine zımnî (örtük) yazara atıfta bulunmaktadır çünkü her ne kadar yazınsal iletişimde bir yazarın var olduğunu varsaymamız gerekiyor olsa da bu yazarın varlığını metin dışında değil metindeki anlam bütünlüğüne ve biçemsel özelliklere bakarak tespit edebiliriz (Boase-Beier 2004, s. 279). Zımnî yazar, yazın metninin okunmasını yönlendiren bir özne konumundadır (Chatman, 1990, s. 74). Bu nedenle, aslında metnin kendisi okurun eseri nasıl okuması gerektiğini gösteren bir zımnî yazar gibidir (Boase-Beier, 2004, s. 279). Okur, gerçek bir yazarın varlığı yerine zımnî yazarın metin içindeki bağlamsal ipuçlarını takip ederek birtakım çıkarımlarda bulunur (Chatman, 1990, s. 83-84).

Yazın metinlerini bağıntı kuramı çerçevesinde ele alırsak, zımnî yazar ile okur arasındaki iletişimi, Sperber ve Wilson'un ifadesi ile (1995, s. 45), "gösterimsel-çıkarımsal bir iletişim" olarak adlandırabiliriz. Gösterimsel-çıkarımsal bir iletişim kurmak isteyen yazar "uyaran niteliği taşıyan bir ipucu" (örneğin, biçemsel bir unsur) üretir ve üretilen bu ipucu yazarın niyetine (mesajına) işaret eder (Sperber \& Wilson, 1995, s. 50). Pateman tarafından belirtildiği gibi (1986, s. 747), yazarın niyetini bu şekilde "gösterme yoluyla ifade etmesi", okura bağıntının üst düzeyde gerçekleşeceğine dair verdiği "üstü kapalı bir garanti" niteliği taşımaktadır.

Bu bakımdan, bağıntı kuramının ortaya koyduğu gösterimsel-çıkarımsal iletişim, belirli biçemsel özelliklerin okur üzerinde nasıl bilişsel etkiler yarattığını açıklamaktadır. Öncelikle, okur biçemsel unsurları (bağıntı kuran ipuçlarını) çözümleyerek belirli kavramsal temsillere erişir. Daha sonraki çıkarımsal aşamada, okur çözümlenen anlamlardan daha karmaşık anlamlar çıkarır ve bu aşamadan sonra bağlamla etkileşime geçerek varsayımlarda bulunur (Clark, 1996, s. 164).

Gutt, yazar ve okur arasındaki gösterimsel-çıkarımsal iletişime örnek olarak heteroglossia kullanımına işaret etmektedir:

Örneğin, belirli bir karakteri toplumsal bir değişke ile konuşturan bir yazarın romanını ele alalım. Yazar açısından, toplumsal bir değişkeyi temsil eden dil özellikleri gösterimsel bir amaç taşımaktadır: okurun bu özellikleri fark etmesi beklenmekte ve bu özellikleri romanın yorumlanmasında 
kullanması istenmektedir. Bu nedenle, [okurla] iletişime geçen kişinin [yazarın] görevi niyetini açığa çıkaracak birtakım göstergeler kullanmaktır ki bu sayede hedef kitle istenen yoruma ulaşabilsin. $(1998$, s. 5)

Çevirmen için de aynı durum geçerlidir. Çevirmen, belirli biçemsel özelliklerin ne tür varsayımlara yol açabileceğini düşünmek zorundadır. Yazın metninde geçen bir lehçenin altında örtük anlamlar yatıyor olabileceğini bilmek durumundadır. Heteroglot sesleri temel alan bir metnin okuru için okuma süreci kolay değildir. Okur dilbilimsel olarak hiç aşina olmadığı bir dil değişkesinin bilişsel olarak yabancılaştırıcı etkisine maruz kalabilir ve sözcelerle iletilmek istenen mesaja ulaşmakta zorluk çekebilir. Heteroglot biçemin altında yatan sanatsal ve ideolojik mesaj(lar)a ulaşma konusunda çevirmene düşen görev, kaynak metindeki iletişimsel ipuçlarının erek metinde de birer iletişimsel ipucu olarak ele alınmasıdır. Gutt'a göre, biçemsel özellikler sadece taşıdığı sanatsal değer nedeniyle değil, erek kitleyi, metinle ilişkili olarak ulaşılması beklenen varsayımlara doğru yönlendirmek için korunmalıdır; bu nedenle, bu tür ipuçlarına "iletişimsel ipuçları" da denir (2000, s. 134).

Edgar Allan Poe'nun 'The Gold Bug' ([1843] 1994) adlı hikâyesi bu duruma güzel bir örnek teşkil etmektedir. 'Altın Böcek' başlığı ile Türkçeye çevrilen bu metni anlayabilmek için öncelikle Jupiter'in konuştuğu dil değişkesini deşifre etmek gerekir. Jupiter'in konuştuğu dil değişkesi okur için çözülmesi gereken bir kod ya da kırılması gereken bir şifre niteliği taşımaktadır. Karakterlerin birbiriyle diyaloglarında da görülebileceği gibi, metinde heteroglot bir sesin varlığı hem karakterler arasında iletişimsizliğe hem de metnin mizahi bir özellik kazanmasına neden olmaktadır:

"Dar! Dat's it! - him neber plain of notin but him berry sick for all dat". "Very sick, Jupiter! Why didn't you say so at once? Is he confined to bed?" "No, dat he aint! - he aint find nowhar dat's just whar deshoe pinch". "Jupiter, I should like to understand what it is you are talking about. You say your master is sick. Hasn't he told you what ails him?". (Poe, 1994, s. 18).

Jupiter, kendisine sorulan soruyu ('[i]s he confined to bed') yanlış anlamıştır (can (he) find (a) bed?). Burada, okur tarafından çıkarımda bulunulması gereken nokta, mevcut iletişimsizliğin söylenen şeylerden değil, söyleniş şeklinden (biçeminden) kaynaklandığı hususudur. Bu diyalog Türkçeye aşağıdaki şekilde çevrilmiştir:

"Mesele burada ya zaten, hiçbirşeyden şikâyeti yok ama gene de hasta işte".

"Demek hasta ha? Neden hemen söylemiyorsun Jupiter, yatıyor mu?"

"Hayır, yatmıyor zaten beni üzen de bu ya".

"Jupiter, ne demek istediğini bir türlü anlamıyorum. Efendinin hasta olduğunu söylüyor, hastalığının ne olduğunu bilmiyorsun. Kendisi sana söylemedi mi?". (Poe 1974, s. 8)

Heteroglot bir sesin ölçünlü dile çevrilmesi sonucunda, okurun dil düzeyinde yabancılaştırıcı bir etki hissetmesine ve anlaşmazlığın kullanılan dil değişkesinden kaynaklandığını farketmesine imkân kalmamıştır. Bunun sonucunda, erek metnin 
bağlamı kaynak metnin bağlamından daha farklı bir hâl almıştır çünkü karakterler arasındaki anlaşmazlık kaynak metinde sözcenin ifade ediliş şeklinden kaynaklanırken, bu durum erek metinde anlatıcının anlama yetisine bağlanmaktadır. Bu noktada bağlam da değişmektedir.

Bilişsel çevre kavramı, bağlam kavramı ile yakından ilişkilidir. Bilişsel çevre, okurun bilişsel düzeyde vardığı varsayımlara dayanmaktadır (Sperber \& Wilson, 1986, s. 46). Okurun bilişsel çevresi, bir metinden hangi anlamı/anlamları çıkardığına bağlıdır. İletişime katılan kişilerin bilişsel çevrelerindeki benzerlikler, bu kişilerin varsayımlarını ortak hâle getirir. Sperber ve Wilson "müşterek bilişsel çevre" kavramını kullanarak, insanlar arasındaki iletişimde nasıl bağıntı kurulduğunu göstermiştir (1995, s. 42). Ancak, bu türden bir müşterek bilişsel çevrenin oluşturulması sadece çevirmenin tercihlerine bağı değildir. Çevirinin yapıldığı hedef kitlenin kimlerden oluştuğu, çeviriye ilişkin beklentilerin ne olduğu, dil düzeyinde kabul edilebilirlik normları ve benzeri konular da başta heteroglossia olmak üzere biçemsel unsurların çevirisi üzerinde büyük bir etkiye sahiptir. Aşağıdaki bölümlerde, çevirmenin hedef kitleye ilişkin varsayımlarının heteroglossia çevirisini nasıl etkileyebileceği üzerinde durulmaktadır.

\subsection{Kitle-Tasarımı Odaklı Biçem Çalışmaları}

Allan Bell tarafından 1984 yılında toplumdilbilimsel bir model olarak ortaya atılan "kitle tasarımı" kavramı, (i) insanların kullandıkları dili iletişime geçtikleri şahısların ihtiyaçlarına ve beklentilerine göre değiştirdiği ya da bu ihtiyaçlar ve beklentiler doğrultusunda uyumlaştırdığını, (ii) biçemsel değişikliklerin (dil değişkesi bazında değişiklikler, dilin yeni ve eski kullanımları bakımından değişiklikler ya da buna benzer diğer değişiklikler) iletişim koşullarında meydana gelen değişikliklere karşı bir cevap niteliği taşıdığını ve (iii) biçemsel değişikliklerin toplumsal değişikliklerden kaynaklanabileceğini ifade etmektedir (Bell, 1984, s. 145). Toplumdilbilim kapsamında kullanılan kitle tasarımı kavramı, yazın çevirisinde kaynak metin biçeminin erek metne aktarılamamasının ve aynı metnin farklı zamanlarda farklı çevirmenler tarafından yapılan çevirilerinde farklı biçemsel özellikleri yansıtmasının nedenlerini açığa çıkarabilir. Çevirmenlerin biçemi, sistematik olarak yaptıkları ve birbiri ile tutarlı olan tercihlerin ışığında belirlenir. Tümevarım yoluyla, bir metni oluşturan ve sistematik olarak gözlemlediğimiz biçemsel özelliklere bakarak, hedef kitlenin beklentileri hakkında ve bu kitleye hitap eden yazar (veya bu çalışma bağlamında çevirmen) hakkında bilgi sahibi olabiliriz (Myers, 1989, s. 3).

Bu çalışma kapsamındaki kitle tasarımı kavramı, gerçek okurlara değil, belirli durumlarda belirli çeviri deneyimlerine ve çevirilerin toplumda nasıl alımlandığının gözlemlenmesine dayanılarak, çevirmenler tarafından okura ait olduğu varsayılan bir takım özelliklere atıfta bulunmaktadır. Bir çeviriye atfedilen amaç, çevirmenin (ya da çevirmenlerin) geçmiş deneyim ve rutinlerinin ışığında çeviri ediminden yola çıkılarak tespit edilebiliyorsa (Nord, 1997), çevirmenlerin biçemsel düzeyde yaptıkları sistematik tercihlere bakılarak erek kitle için kitle tasarımı tespiti de yapılabilir.

Bell, kitle tasarımının dil değişkeleri düzeyinde görülebileceğini ve insanların kitle tasarımı yoluyla başka insanların beklentilerine ayak uydurduklarını belirtmektedir 
(1984, s. 197). Başka bir deyişle, insanlar iletişim kurdukları insanların beklentilerine göre biçemsel özelliklerini belirlemektedir. Bu bağlamda, çevirmenlerin de farklı hedef kitleler için farklı biçemler tasarlayabildiğini göz önünde bulundurmalıyız. Bell’in çalışmasından elde edilen bulguların ışığında, erek dil okurunun beğenisini kazanmak ya da yapılan çevirinin toplumda kabul edilebilir bir çeviri olarak alımlanmasını sağlamak için çevirmenlerin - hedef kitleye özgü olduğunu varsaydıkları özelliklere dayanarak - kaynak metnin biçemsel özelliklerinde bir takım değişikliklere gidebileceği söylenebilir.

\subsection{Heteroglossia Çevirisine Kitle-Tasarımı Odaklı Bir Yaklaşım}

Erek metindeki heteroglot seslerin çeviriye yansıtılması konusu birçok araştırmacının gündemine girmiştir. Örneğin, Suominen (2001) "heteroglot sesleri [romanın] iskeleti[ni] hareket ettiren ve romana nihai şeklini ve anlamını veren kaslara" benzetmekte ve heteroglossia'nın çeviride yeniden oluşturulmasının gerektiğinin altını çizmektedir. McGill Üniversitesi'nde bir çeviribilim araştırma grubu olan GRETI'nin üyesi olarak çalışan Lane-Mercier (1995, s. 109), Faulkner'ın (1940) The Hamlet adlı eserindeki toplumsal değişkelere dayalı dil kullanımının daha önce yapılan Fransızca çevirilere yansıtılamamış olması sebebiyle, eserin mizahi etkisinin çeviride oluşturulamadığını ve bu durumun Faulkner'ın Fransız okuru tarafından "trajik bir yazar" olarak alımlanmasına neden olduğunu belirtmiştir. Bu durum, araştırma grubunun eseri yeniden çevirmesine ve çeviri için erek dil içindeki bir toplumsal değişkenin seçilmesine zemin hazırlamıştır.

Lane Mercier, bazı yazın örneklerinde "düzgün yazma" ve toplumda "kabul gören düzgün bir dil" kullanma motivasyonuyla heteroglot seslerin ve bu seslerin altında yatan ideolojik mesajların çeviriye yansıtılamadığını belirtmiştir (1995, s. 109). Ölçünlü dilin yazın alanında normatif ve düzenleyici bir rol oynaması, geleneksel imla kurallarının metnin toplum karşısında kabul edilebilirlik şansını yükselterek simgesel bir rol oynaması, dilbilgisi ve yazım kurallarının "düzen, gelenek, otorite, hiyerarşi ve kurallar" açısından sosyal ve politik bir düzenin tesis edilmesi için önemli bir işleve sahip olması nedeniyle ölçünlü olmayan dil kullanımlarının çoğu zaman yazın eserlerinde kullanılamadığı ya da kullanımının sınırlandırıldığı görülmektedir (Cameron, 1995, s. 95). Bakhtin yazın dilinin genellikle "homojen" bir yapıya sahip olduğunu ve yazın dili ile ölçünlü dilin eş anlamlı olarak algılanması nedeniyle "yazın dili[nin], ulusun kültürel, siyasal ve coğrafi bütünlüğünü" temsil ettiğini vurgulamıştır (2001, s. 279). Bu nedenle, yazın eserlerinde kullanılan heteroglot sesler çeviride genellikle filtreleme işlemine tabi tutulmaktadır.

GRETI'nin “politik, tarihsel ve kurumsal” bir işleve sahip olduğunu belirten LaneMercier (1995, s. 117-118), bu nedenle Faulkner'ın The Hamlet eserindeki heteroglot sesleri (Mississipi'de yaşayan insanların sesini) özellikle seçtikleri yerel bir Quebec aksanıyla Fransızcaya çevirdiklerini açıklamıştır. Kaynak metindeki heteroglot seslerin erek dildeki heteroglot seslerle çevrilmesiyle

- $\quad$ okurun toplumdilbilimsel "beklentilerinin iddialı bir şekilde sarsılması";

- okurun "okuma alışkanlıklarının" ve yazın eserlerinden "beklentilerinin" yıkılması; 
- $\quad$ Faulkner'ın heteroglot biçeminin erek okura yansıtılamamasından dolayı Fransa'da "trajik, monolojik bir yazar" olarak tanınmasının önüne geçilerek, okurun alışılagelmiş "okuma şemalarının" kırılmaya çalışılması ve

- $\quad$ yazın alanında ölçünlü Fransızca ile dil değişkeleri arasındaki "güç dengesizliğini" yansıtarak Quebec gibi "marjinalleştirilmiş" bir sosyo-biçemsel katmana dikkat çekilmesi amaçlanmıştır (Lane-Mercier, 1995, s. 117).

Görüldüğü gibi, GRETI grubunun üyeleri, çeviri için belirli bir kitle tasarımından yola çıkarak bu kitle tasarımına özgü olduğu varsayılan alışkanlıkları kırmak için belirli bir biçemsel strateji ile çeviri yapma yoluna gitmiştir. Diğer yandan, GRETI üyelerinin, zihinlerinde oluşturdukları kitle tasarımından hareketle, tamamen bu kitlenin beklentilerine karşılık vermek için çeviri yapmayı tercih edebileceğini de göz önünde bulundurmamı gerekir. Belirli bir kitle tasarımı çerçevesinde hareket etmek, okur kitlesinin beklentilerini ve ihtiyaçlarını bilmek anlamına gelir ve bu beklentilere karşılık vermek ya da beklentileri yıkmaya çalışmak çevirmenin (ve/veya editör, yayınevi sahibi gibi diğer eyleyicilerin) tercihidir.

Lane-Mercier, kaynak dile özgü bir değişkenin erek dile ait bir dil değişkesi ile çevrilmesinden dolayı bazı edimbilimsel ve kültürel anlam değişikliklerinin ortaya çıkabileceğinin farkında olduklarını, buna rağmen, bu şekilde bir biçemsel strateji izlenmesinin kaynak metnin "öteki" olgusunu ön plana çıkarması nedeniyle, söz konusu değişikliklerin "tolere edilebileceği[ni]" düşündüklerini belirtmiştir (1995, s. 117). Bu örnekte olduğu gibi, heteroglot seslerin, Lane-Mercier'in (1995) ifadesiyle, "düzgün yazım" ve Bourdieu'nün (1991) ifadesiyle "meşru dil" kullanımına karşı olarak kullanılmasının ideolojik bir gösterge olduğunun farkında olmamız gerekmektedir.

Heteroglot seslerin yazın metinlerinde kurgusal olarak temsilinde, ötekinin ön plana çıkarılması hedefleniyorsa, dilin "kendi ve öteki arasındaki diyalektik ilişkisi içinde barındırdığı her türlü güç denge(sizlik)leri ve hiyerarşileri” ile birlikte yansıtılması gerekmektedir (Lane-Mercier, 1995, s. 109). Bu durumda, heteroglossianın yazın metinlerinde temsili, "düzgün yazım hegemonyası" ve toplumda egemen olan ideolojinin etkilediği söylemlerle oluşturulan kimlik ve güç ilişkileri ile "örtük bir mücadele stratejisi[nin]" çeviriye de aktarılması beklenmektedir (Lane-Mercier, 1995, s. 109).

GRETI çalışma grubunun kitle-tasarımı odaklı yaptığı çeviriye ek olarak, Trainspotting'in Bowman ve Mouwad tarafından Joual konuşan kitle için yaptığı çeviriyi de örnek verebiliriz. Joual, Montreal'de konuşulan ve işçi sınıfına ait bir dil değişkesidir. Çevirmenlerin Trainspotting'deki dil değişkelerini erek metinde Joual ile yeniden oluşturmaya karar vermesi, heteroglot seslerin hedef kitleye ait toplumdilbilimsel, kültürel ve ideolojik art alanla bağlantılı olarak çevrilmesinin diğer bir örneğidir.

Heteroglot seslerin belirli bir kitle için sistematik olarak çevrilmemesi de kitletasarımı odaklı çeviri edimini akla getirmektedir. Türk toplumunda, gazetelerde ve televizyonlarda düzgün konuşma ve düzgün yazma konusunda düzenli olarak bilinçlendirme yapılmakta ve Türkçenin yanlış kullanılması ile ilgili örnekler gösterilmektedir. Kamusal alanda Türkçenin düzgün kullanılmaması nedeniyle, 
çocukların ve yetişkinlerin dil kullanımının bozulduğuna, ölçünlü dilin bozulduğu durumlarda kültürün de zarar gördüğüne ve insanların dili düzgün kulanma konusunda özen göstermesi gerektiğine dikkat çekilmektedir. Düzgün, "sade ve okunaklı Türkçe" kullanımı dil devriminin gerçekleştirilmesi ile birlikte bir norm hâline gelmiştir (Paker, 1986, s. 419). Bu olgu, Cumhuriyet'in ilk yıllarında yapılan çevirilerde, özellikle de dil değişkeleri içeren kaynak metinlerin çevirilerinde gözlemlenebilir. Erken cumhuriyet dönemi çeviri politikaları, Türk kültürünü "arı bir bütün” olarak temsil etmek üzere "etnik ve dil birliğine" dayanan dil kurallarını temel almıştır (Seyhan, 2005, s. 283). Hepçilingirler (1999) gibi önemli dilbilimciler, ölçünlü dil kullanımının gerekliliğine dikkat çekmektedir. Dil ile ilgili "doğru kullanım", "düzgünlük" ve "güzellik" gibi düşüncelerin kültürel olarak benimsenmesi ve kabul görmesi meşruiyet ve ulusal birlik için büyük bir önem taşımaktadır (Gall, 1998, s. 325). Bu nedenle, heteroglot sesleri barındıran yabancı metinler genellikle yayın endüstrisinde egemen olan ve resmî düzeyde kabul gören dillere çevrilmekte ve farklı seslerin biçemsel ve anlamsal düzeyde sahip olduğu zenginlikler çeviriye aktarılamamaktadır (Venuti, 1998, s. 162).

Türk toplumunda dil değişkelerinin zaman içinde ölçünlü dile girerek Türkçeye zarar verdiği görüşü yaygındır (Yağcıoğlu, 2004, s. 186). Bu durum, çevirmenlere belirli bir kitle tasarımı sunmaktadır. Yazın eserlerine baktığımızda, yazarların genellikle ölçünlü dil kullanımını tercih ettikleri ve dil değişkesi kullanan Yaşar Kemal gibi bazı yazarların da bu tür biçemsel kullanımlarına sınırlı olarak yer verdiklerini görebiliriz. Bu sınırlandırma ya da filtreleme işlemi, yazarın okunabilirliği sağlama amacına da bağlıdır. Çevirmenler için de aynı durum geçerlidir. Genç yazarların ve çevirmenlerin Türkçeyi yanlış kullandığının belirtilmesi (Özel, 2000, s. 19), Türkçeyi yabancı kelimelerin etkisinden kurtarma gereksinimi, yazılı dil ile konuşma dili arasındaki farklılığı giderme ihtiyacı ve dil yolu ile toplumsal uyum ve birliktelik sağlama hedefi için önlem alınması gerektiğine dair söylemler (Özel, 2000, s. 59), çevirmenlerin zihinlerinde oluşturduğu kitle tasarımına uygun olarak çeviri yapmasını da beraberinde getirebilir. 23-24 Eylül 1999 tarihlerinde düzenlenen Türkçenin Zenginleştirilmesi Kurultayı'nda, dilbilimciler ile yazarlar arasında dil kullanımına ilişkin bir tartışma yürütülmüştür (Kongar, 2003, s. 37). Dilbilimciler, Türkçenin yazın metinlerinde kullanılması ile dil normlarından sapılmaması gerektiğine işaret ederken; bazı yazarlar yazın metni üretilirken Türkçenin bozulduğu fikrine karşı çıkmıştır (Kongar, 2003, s. 37).

Dile ilişkin yazın alanındaki kaygılar, Doğançay-Aktuna'ya göre (2004, s. 14-15), Türkçenin yozlaştırılması (yabancı sözcükler ve ölçünlü olmayan dil unsurlarının kullanımı), Türkçenin imla ve ses özelliklerine uymayan dil kullanımları ve dil bilincinin yeteri kadar geliştirilememiş olması nedeniyle dilin çoğu zaman düzgün kullanılması şeklinde özetlenebilir. Ayrıca, 2876 sayılı kanun çerçevesinde, Türk Dil Kurumu'nun Türkçeyi nesiller arasında birleştirici ve bütünleştirici bir köprü olarak düzgün bir şekilde kullanan, dil bilincini ve Türkçe sevgisini yayan ve dilin korunması için çaba harcayan yazar ve şairlere ödüller vermesi de Türk okuru için çeviri yapan çevirmenin zihninde belirli bir kitle tasarımına dair ipucu oluşturmaktadır. Tüm bu bilgilerin ışığında, aşağıdaki bölümde, Welsh'in Trainspotting adlı romanındaki heteroglot seslerin Türkçeye nasıl aktarıldığı ele alınacaktır. 


\section{Analiz}

\subsection{Irvine Welsh}

1961 yılında İskoçya'da doğan Welsh, Edinburgh'un işçi kesimlerinde geçen çocukluk döneminin ardından 16 yaşında okulu terk ederek çalışmaya başlamıştır. Punk hareketlerinin başladığı ve uyuşturucu kullanımının arttığı yıllarda Londra'ya göç eden Welsh, 1980'li yılların sonunda Edinburgh'a geri dönmüştür. Illk kitabı olan ve kısa hikâyelerden oluşan The Acid House'u 1994 yılında yayımlamıştır. Bu kitabı, kült eser olarak kabul edilen ve 1993 yılında okur ile buluşan Trainspotting adlı romanı takip etmiştir.

Welsh ikinci romanı olan Ecstasy'i 1995'te yazmıştır. 1998 yılında ise Filth adlı romanı yayımlanmıştır. Daha sonra sırasıyla Glue (2001), Reheated Cabbage (2009), Skagboys (2012), The Sex Lives of Seamese Twins (2014), A Decent Ride (2015), The Blade Artist (2016), Dead Men's Trousers (2018) yayımlanmıştır.

Eserlerinde genellikle uyuşturucu kullanımına odaklanan Welsh, 1960'lı yıllardan günümüze İskoç kimliği ve işçi sınıfı temalarını kullanmıştır. Futbol, holiganizm, cinsellik, sınıf farklılıkları gibi konular da Welsh'in romanlarında yerini almıştır. İskoç İngilizcesi ve bu dile özgü farklı dil değişkelerini kullanan Welsh, geleneksel ortografik pratiklerini yıkarak okura farklı bir okuma tecrübesi yaşatmaktadır. Welsh'in eserlerini yayımlayan yabancı yayınevleri, okurun işini kolaylaştırmak için Welsh'in kitaplarının sonuna sözlükçeler eklemektedir.

\subsection{Trainspotting}

Uyuşturucu kullanan bir grup İskoç gencin hayatını anlatan Trainspotting, uyuşturucu bağımlılığı temasını etkili bir şekilde anlatmakla birlikte, politik altmetni güçlü olan bir romandır. İngiltere'nin İskoçya üzerindeki sömürge faaliyetlerine odaklanan romanda, sömürüye dayalı düzen içerisinde uyuşturucu kullanarak ayakta kalmanın çaresini arayan karakterler kendilerine sunulan düzeni ve dayatılan hayatı reddetmektedir. İçlerinden geldiği gibi yaşayan karakterler, kullandıkları uyuşturucunun etkisiyle hayal dünyasından gerçek dünyaya uyum sağlamaya çalışmaktadır. Romanda, Britanya'da Thatcher sonrası dönemde büyük zorluklar yaşayan İskoç gençliğinden bir kesit sunulmaktadır. Renton, Spud, Begbie ve Sickboy adlı karakterler alkol ve uyuşturucu bağımlılıklarına ve işsiz olmalarına rağmen, daha güzel bir hayat yaşamak istemektedirler.

Trainspotting'de, biçemsel olarak, hem orta sınıf hem de orta sınıfın dil değişkelerine karşı olan tutumu eleştirilmektedir. Kırk dört bölümün yirmisi Renton, ikisi Sickboy, üçü Spud, ikisi Begbie ve sekizi bilinmeyen bir anlatıcı tarafından anlatılmaktadır. Karakterler, roman boyunca birbirinden farklı dil değişkeleri kullanmaktadır. Ancak, sadece Renton ve Begbie gerektiğinde konuştuğu dil değişkesinden ölçünlü dile geçiş yapabilmektedir. Osborne (1996), Spud gibi karakterlerin ölçünlü dil konuşamamaları nedeniyle toplumda hep önemli sosyal statülerden yoksun, zor bir hayat yaşadıklarını ve bu nedenle ne kadar kötü şeyler yaparlarsa yapsınlar heteroglot sesleri nedeniyle okurun sempatisini kazandıklarını 
belirtmiştir. Dil değişkeleri, romanlarda bazen mizahi bir etki yaratmak için kullanıldığından, heteroglot seslere sahip olan karakterlerin genellikle romana renk katmak için var olduğu düşünülmektedir. Ancak, Welsh'in romanında heteroglot sesler orta sınıfın üstünlüğüne karşı direnmek için ideolojik bir mesaj vermek üzere kullanılmaktadır (Craig, 2006, s. 122).

Benedict Anderson'un (1983) "hayali cemaatler" kavramı ile, bir toplumu oluşturan grupların sahip olduğu birtakım farklılıklara rağmen, kurgulanmış ve kolektif bir tasarım olarak dilde ve söylemde oluşturduğu birlik sayesinde ulus hâlini aldığı belirtilmektedir. Cronin (2003), İskoç yazarların ölçünlü İngilizceye meydan okuyarak kendi kimliklerini dil ve söylem yoluyla inşa ettiğini belirtmektedir. Bu nedenle, İskoçların dilsel ve kültürel ötekiliğinin eserlerinin çevirilerine de yansıtılması büyük bir önem taşımaktadır çünkü İskoçya, İmparatorluğun genişlemesinde ve İngilizcenin dünya dili hâline gelmesinde aktif bir katılımcı rolü oynamasına rağmen, kolonileştirilmiş uluslarla aynı kaderi paylaşmaktadır (Craig, 1988, s. 5). 1970 ve 1980'li yıllardaki toplumsal ve siyasal gelişmeler, İskoçya'nın Britanya topraklarında egemen güce başkaldıran bir ulus olarak tasvir edilmesine neden olmuştur (March, 2002, s. 2). İskoç milliyetçiliği, bu nedenle, birçok yazın eserinde duygusal bir dil politikası ile belirgin hâle getirilmektedir.

Benedict Anderson'un hayali cemaatler kavramı ile çizdiği kuramsal çerçevede kimlik tek ve monolitik bir zeminde tasvir edilmektedir. Bu çerçevedeki ulusal kimlik, sabit ve değişmezdir; ayrıca, kimliğin başka kimliklere meydan okuyan diyalektik bir ilişki içinde inşa edilebileceği fikri Anderson tarafından göz ardı edilmektedir. Trainspotting adlı romanda farklı İskoç karakterlerin ölçünlü İngilizceye karşı tek bir dil ve kimlik yerine, birden fazla İskoç dil değişkesi ile konuşmasıyla, ulus inşasının karmaşık yapısı gözler önüne serilmektedir. Bu nedenle, Trainspotting, bir ulusun farklı etnik kimliklerin bir araya gelmesi örneğinden yola çıkarak, Anderson'un ulusal homojenlik tezine biçemsel olarak tezat oluşturan bir örnek teşkil etmektedir (Corbett, 1999, s. 161).

Trainspotting'in karakterleri, aynı zamanda, romanın farklı anlatıcıları olarak karşımıza çıkmakta ve okuma sürecinde kendilerine özgü dil değişkeleri ile birbirinden ayırt edilebilmektedir. Örneğin, Sickboy taciz etmek ve dolandırmak istediği bir kişi ile karşılaştığında ölçünlü dile geçiş yapması ile diğer anlatıcılardan ayrılmaktadır. Renton ise heteroglot sesine rağmen ağdalı ve felsefi dil kullanımı ile diğer anlatıcılardan ayrılmaktadır. Renton, sık sık Latince terimler kullanarak filozof edasıyla konuşsa da diğer anlatıcılara kıyasla en argolu üslupla konuşan anlatıcıdır. Begbie'nin dili en alt toplumsal statüyü temsil etmektedir. Spud'ın dil kullanımı ise, entelektüel düzeyde yaşadığı geri kalmışlığın bir göstergesi olarak karşımıza çıkmaktadır. Her şeyi bilen ve karakteranlatıcıların dışında kalan bir anlatıcı olarak karşımıza çıkan isimsiz anlatıcı ise sadece ölçünlü İngilizce kullanarak diğer anlatıcılardan ayrılmaktadır.

Trainspotting romanında ön plana çıkan başka bir biçemsel özellik, tabu kelimelerin heteroglot seslerin ayrılmaz bir parçası olarak kullanılmasıdır. Tabu kelimeler romanda heteroglot sesler ile yoğun bir düzeyde iç içe geçmiş ve kadınlığı aşağılayıcı bir şekilde kullanılmıştır. Roman, Booker Prize ödülüne aday gösterilmiş olmasına rağmen feminist hassasiyetleri zedelediği ve cinsiyet ayrımcılığına dayanan tabu kelimeleri sıklıkla kullandığı için jüri üyeleri tarafından reddedilmiştir. 
Yukarıda değinilen ve önemli mesajlar taşıyan biçemsel özelliklerin Türkçeye nasıl aktarıldığını ve bu aktarım sırasında yazar ve okur arasında kurulan bağıntı açısından çeviride bir değişiklik görülüp görülmediğini incelemek üzere romanı ve çevirisini temsil eden örnekler aşağıda ele alınmaktadır.

\section{3. Örnekler}

\section{Kaynak Metin}

-No fuckin shy, they British Rail cunts, eh? Ah sais, nudging the burd next tae us.

-Pardon? It sais tae us, sortay soundin likes, 'par-dawn' ken?

-Whair's it yis come fae then?

-Sorry, I can't really understand you...These foreign cunts've goat trouble wi the Queen's fuckin English, ken. Ye huv tae speak louder, slower, n likesay mair posh, fir the cunts tae understand ye.

-WHERE...DO...YOU...COME...FROM?

-That dis the fuckin trick. These nosey cunts in front ay us look roond. Ah stares back at the cunts. Some fucker's oan a burst mooth before the end ay this fuckin journey, ah kin see that now.

-Ehm...we're from Toronto, Canada.

-Tirawnto. That wis the Lone Ranger's mate, wis it no? ah sais. The burds jist look it us. Some punters dinnae fuckin understand the Scottish sense ay humour.

-Where are you from? The other burd sais. Pair ay rides naw. That ridheided cunt made a good fuckin move sittin here, ah kin tell ye.

-Edinburgh, Rent goes, tryin tae sound aw fuckin posh, ken. Fuckin smarmy rid-heided cunt. He's aw ready tae steam in now, aw Joe-fuckinCool, once Franco breks the fuckin ice (Welsh, 1994, s. 115).

\section{Erek Metin 1}

-Britanya Demiryollari'nin ibnelerinde de hiç utanma kalmamış diil mi, dedim kızı kendime çekerek.

-Pardon? dedi bana, sanki 'affedersiniz?' der gibi.

-Siz nerdensiniz ki?

-Özür dilerim. Sizi gerçekten anlamıyorum. Bu yabancı karıların kraliçenin İngilizcesiyle kesin bi problemleri vardı. Onların sizi anlaması için yüksek sesle, yavaşça ve daha kibarca konuşmanız gerekir.

-NERE...DEN...GELI...YOR...SUNUZ? 
Numara buydu iste. Önümüzdeki bazı tipler etrafa bakındı. Ben tekrar karılara döndüm. Şimdiden belli ki bu yolculuk bitmeden birilerinin canı fena yanıcak!

-Şey, biz Torontoluyuz, Kanadalı.

-Tironto. Orası Yalnız Kovboy'un memleketi diil mi yav? dedim. Karılar öylece baktı. Bazı gerzekler İskoçların espri anlayışını kesinlikle kaldıramıyorlar.

-Siz nerelisiniz, dedi öbür karı. Bayaa ilgiliydi. Bizim kızıl saçlı herif buraya oturmakla kesin iyi bi iş yapmıştı.

-Edinburgh, dedi Rents, sesini nazikleştirmeye çalışarak. Kibarlığını siktiminin ibnesi! Franco karıları maysştırdı tabii, simdi Esas Oğlan ayaklarına yatmak kolay! (Welsh, 2001, s. 135-136).

\section{Erek Metin 2}

"Hiç utanma yok bu Britanya Demiryolu amcıklarında, değil mi," diyorum yanımızdaki çıtıra.

"Pardon?" diyor bana, tuhaf aksanıyla.

"Nerdensiniz bakiyim siz?"

"Afedersin seni anlamıyorum..." Bu yabancı amcıkların Kraliçenin İngilizcesi ile sorunları var. Yüksek sesle, yavaş ve biraz daha kibar konuşman gerekiyor anlayabilmeleri için.

“NERDEN GELIYORSUNUZ... SiZ?”

Bu meseleyi hallediyor. Önümüzdeki meraklı amcıklar dönüp bana bakıyorlar. Ben de dosdoğru onlara bakıyorum. Bu yolculuk tamamlanmadan birilerinin ağzı burnu kırılacak, bunu şimdiden görebiliyorum.

\section{"Şey...Biz Kanadalıyız, Torontolu."}

"Toronto. Maskeli Süvarinin Kızılderili kankasının adıydı, değil mi?"diyorum. Kızlar bön bön bakıyolar bana. İskoç mizahını anlamak herkesin harcı değil (Welsh, 2010, s. 120-121).

Kaynak metinde, karakterler arasındaki anlaşmazlık Begbie'nin heteroglot sesinden kaynaklanmaktadır. Begbie'nin 'whair's it yis come fae then' sorusunun turist tarafından anlaşılamaması nedeniyle ölçünlü dilde 'where...do...you...come...from' şeklinde sorulduğunda turistten beklenen cevap gelmiştir. Ancak her iki erek metinde de heteroglot sesin yansıtılmamış olması nedeniyle, aynı durum sırasıyla 'siz nerdensiniz ki' ve 'nere...den...geli...yor...sunuz' gibi sorularla oluşturulmaya çalışılmıştır. Bu nedenle, heteroglot seslerden kaynaklanan iletişimsizlik erek metinlerde ortaya çıkarılamamıştır. Aynı nedenle, kaynak dil okuru ile erek dil okurunun aynı bağlama sahip olduğu 
söylenemez. Ayrıca, Begbie'nin 'yüksek sesle, yavaş ve gösterişli' bir dil ile kastettiği şey kaynak metinde ölçünlü dil kullanımıyken, çevirilere 'kibar' bir konuşma şeklinin daha anlaşılır olduğu fikri yansımıştır.

Thomson, İskoç dil değişkelerinin ölçünlü İngilizce ile diyalojik ve diyaletik bir ilişkiye girerek okur üzerinde yabancılaştırıcı bir etki bıraktığını vurgulamıştır (2004, s. 62). Türkçe çevirilerde, ortografik düzeyde, okuru metne yabancılaştıran bir etki görülmemektedir. Trainspotting'deki heteroglot seslerin yazı diline aşırıya kaçılarak yansıtılması nedeniyle kaynak metin okuru "dil içi bir şiddet[e]" maruz kalmaktadır (Talib, 2002, s. 33). Romandaki heteroglot seslerin "yıkıcı, tahrip edici ve bölücü" etkisi ile İskoçların böyle bir etki yaratmaktan haz duyduğu mesajı verilmeye çalışılmıştır (Kennedy, 1996, s. 19). Apter'in belirttiği gibi, romandaki heteroglot sesler, İngilizceyi "zedeleyen", alt-kültüre ait bir konuşma tarzının oluşturulmasına (2006, s. 155) ve İskoçya toprakları dışında kalan Anglofon okura zorlayıcı ve yabancılaştırıcı bir okuma tecrübesinin kazandırılmasına neden olmaktadır. Türkçe çevirilerde ölçünlü dili bozan ya da, Apter'in (2006) ifadesiyle, dili 'zedeleyen' heteroglot bir ses kullanılmamıştır.

Buna rağmen, ilk çevirmen ortografik düzeyde günlük konuşma dilini (' $r$ ' sesinin düşürülmesi yoluyla) yazı diline yansıttığı için bazı eleştirmenler tarafından dil kullanımına özen göstermediği ve "bir ilkokul öğrencisini bile rahatsız edebilecek dil hataları" yaptığı gerekçesiyle eleştirilmiştir (Gökpek, 2006). Bu tür eleştiriler, yazın alanında ölçünlü dil kurallarına riayet edilmemesi hususunda tahammül düzeyinin düşük olduğunu göstermektedir.

Yukarıdaki örneğe bağıntı kuramının perspektifinden bakacak olursak, heteroglot seslerin, kaynak metinde, okurun birtakım bağlamsal etkilere ulaşması ve böylece güçlü bir bağıntının ortaya çıkarılması için kullanıldığını görmekteyiz. Çevirilerde gözlemlenen müdahaleler, erek okurun, kaynak-metin okurunun okuma sürecinde kullandığı bağlamsal ipuçlarından yoksun kalmasına ve birçok sezdirimi fark edememesine neden olmaktadır.

Ayrıca, kaynak metinde 'cunt' ve 'fuck' kelimelerinin sıklıkla kullanılması okurun eril tahakküme ilişkin çıkarımlarda bulunmasına olanak sağlamaktadır. Tarih boyunca, yazın metinlerinde eril kültüre ilişkin olarak farklı şekillerde göndermelerde bulunulmuş; eril tahakküm iş bölümü, ekonomik fırsat, siyaset ve kamu alanlarında erkek egemenliği ile birlikte erkeklerin kadına yönelik fiziksel ve cinsel şiddeti bağlamında ele alınmıştır. Kadınlığın cinsel işlev ile sınırlandırılması, eril tahakkümün kendisini söylem düzeyinde ön plana çıkarmasının en önemli göstergelerinden biridir. Trainspotting'de 'cunt' ve 'fuck' sözcüklerinin küfür etmek amacıyla yoğun olarak ve hatta aşırıya kaçılarak kullanılması, hem biçemsel olarak hem de söylem düzeyinde, romana konu olan altkültürde eril tahakkümün durumuna ilişkin bağlamsal ipuçları vermektedir. Türkçe çevirilerde 'cunt' ve 'fuck' kullanımına sıklıkla yer verilmesi, erek metin okuruna bu bağlamda kaynak metin yazarı ile müşterek bir bilişsel çevre oluşturma imkanı sağlanmıştır. Ancak, ilk çeviride 'cunt' kelimesinin, ikinci çevirideki kadar yoğun kullanılmadığını da belirtmek gerekir.

\section{Kaynak Metin}


Ah have oedipal feelings towards ma mother and an attendant unresolved jealousy towards ma father. Ma junk behaviour is anal in concept, attention-seeking, yes, but instead of withholding the faeces tae rebel against parental authority, ah'm pittin smack intae ma body tae claim power over it vis-à-vis society in general. Radge, eh? (Welsh, 1994, s. 185)

\section{Erek Metin 1}

Anneme karşı ödipal bazı eğilimlerim ve babama karşı da gizli bi kıskançlık duygum vardı. Benim uyuşturucu alışkanlığım aslında temelinde anal bi davranıştı, ilgi arayışı içindeydim. Ama toplumdaki baba otoritesine açıkça isyan etmek yerine toplumla yüzleşmek ve onlara üstünlük taslamak için kendi bedenime uyuşturucu atıyodum. Tamam mı? (Welsh, 2001, s. 213)

\section{Erek Metin 2}

Oedipus kompleksim vardı, babama karşı çözümlenmemiş bir kıskançlık duyuyordum. Eroin kullanmam kavramsal olarak analdı, ilgi çekmeye yönelikti, evet fakat ebeveyn otoritesine isyan etmektense genel topluma karşı bir güç elde edebilmek için damarlarıma eroin basıyordum. Çılgınlık değil mi? (Welsh, 2010, s. 190)

Kaynak metinde, Renton'un heteroglot sesi ile entelektüel düzeyi yüksek bir kesit dilin birlikte kullanılmasının altında yatan mesaj, 'ödipal', 'anal' ve benzeri kelimelerin heteroglot seslerden de çıkabileceğidir. Örnekte, heteroglot sesler ile "soyut, uzmanlık bilgisi gerektiren kelimelerin" bir araya getirilmesi ile bu sözcüklerin kullanımının ölçünlü dil ile sınırlandırılamayacağı mesajı verilmektedir (Craig, 2006, s. 134). Kaynak metindeki entelektüel tarzın Türkçe çevirilerde oluşturulmuş olmasına rağmen, heteroglot sesin çevirilere yansıtılmadığını görmekteyiz. İlk çeviride, dil değişkesi yerine 'bi' ve 'atıyodum' gibi günlük konuşma dilinde sık rastlandığı şekliyle ' $r$ ' harfi düşürülmüştür. İkinci çeviride ise herhangi bir ortografik değişiklik yapılmamıştır. Bu çerçevede vurgulamamız gereken diğer bir nokta ise, kaynak metinde 'faeces' ve 'shit' arasındaki ayrım gözetilerek daha üstün bir kesit dile ait olan 'faeces'in kullanılmış olmasına rağmen, her iki çeviride de, bu durumun okura yansıtılmamış olmasıdır. Bu durumun nedeni, çeviride entelektüel düzeyi yüksek bir kesit dili bozabilecek herhangi bir kelimenin kullanımından ya da bu kelimenin yaptığı çağrışımdan kaçınııması olabilir.

Örneklerden de anlaşılabileceği gibi, kaynak metin yazarı iletmek istediği birçok mesajı heteroglot sesler yoluyla ortaya koymaktadır. Kaynak metnin genelinde heteroglot sesler bağlamsal birer ipucu olarak kullanılmıştır. Bu bağlamsal ipuçları ile (i) karakterlerin arasındaki iletişimsizliğin nedeni yansıtılmakta; (ii) karakterlerin ülkelerini hâkimiyeti altına alan güce karşı dil düzeyinde verdiği mücadele gösterilmekte; (iii) İskoçyanın kendi içinde bile homojen bir dile sahip olamaması nedeniyle İskoç kimlik inşasında ötekinin ve ötekileştirilenin kim olduğunun sürekli olarak sorgulanmasına vurgu yapılmakta; ve (iv) karakterlerin uyguladığı şiddetin romandaki fiziksel eylemleriyle sınırlandırılmayıp, okura zor bir okuma süreci yaşatan dil içi şiddete kadar uzandığına işaret edilmektedir. 
Buradan da anlaşılacağı gibi, yazar ile okur arasında heteroglot sesler yoluyla gösterimsel-çıkarımsal bir iletişim kurulmuştur. Gösterimsel-çıkarımsal iletişimin temel unsurunu oluşturan heteroglot sesler okurun toplumsal, kültürel ve ideolojik düzeyde önemli çıkarımlarda bulunmasına neden olarak, bu sesler ile metin arasında bağıntı kurmasına neden olmaktadır. Ancak, Türk toplumunda heteroglot seslerin yazın alanında nadiren kullanılması ve okurun aşina olmadığı ortografik değişikliklerin özellikle çevirilerin kabul edilebilirlik şansını düşürme potansiyeli nedeniyle, heteroglot seslerin yarattığı türden bir gösterimsel-çıkarımsal ipucu çevirilerde bulunmamaktadır.

\section{Sonuç}

Heteroglossia kavramından yola çıkarak dil değişkelerinin yazın metinlerinde nasıl bir rol oynadığını incelemeyi ve heteroglot seslerin çeviri yoluyla aktarımı söz konusu olduğunda hedef kitlenin yazın geleneklerinin, dil normlarının ve dil üzerine oluşturduğu söylemlerinin çeviriyi nasıl etkileyebileceğine ışık tutmayı amaçlayan bu çalışmada, Welsh'in Trainspotting adlı eserinin iki Türkçe çevirisinden örnekler incelenmiştir. Romanda, İskoç dil değişkelerinin fonetik yazıma aktarılması ile her bir karakter kendisine özgü ortografik özelliklerle diğer karakterlerden ayırt edilebilmektedir. Ayrıca, heteroglot sesler romanda bağlamsal bir ipucu olarak kullanılmıştır. Bu bağlamsal ipuçları ile bir yandan karakterlerin ülkelerini hâkimiyeti altına alan güce karşı dil düzeyinde verdiği mücadele vurgulanmış; diğer yandan, İskoçyanın kendi içinde bile homojen bir dile sahip olamaması nedeniyle İskoç kimlik inşasında ötekinin ve ötekileştirilenin kim olduğunun sürekli olarak sorgulandığı ima edilmiştir.

İncelenen Türkçe çevirilerde ölçünlü dili bozan ya da, Apter'in (2006) ifadesiyle, ölçünlü dil kullanımını "zedeleyen" heteroglot bir ses kullanılmamıştır. Heteroglot seslerin kaynak metne ortografik düzeyde aktarılması sürecinde aşırıya kaçılması nedeniyle kaynak metin okurunun, Talib'in ifadesiyle (2002, s. 33), maruz bırakıldığı "dil içi şiddet" erek dil okuru tarafından yaşanmamaktadır. Ancak, şunu da belirtmek gerekir ki, kaynak metinde olduğu gibi, erek metinlerde de 'cunt' ve 'fuck' kelimelerinin sıklıkla kullanılması, erek dil okurunun eril tahakküme ilişkin çıkarımlarda bulunmasına olanak sağlamıştır.

Trainspotting'in iki farklı çevirmen tarafından yapılan çevirilerinde, heteroglot seslerin erek metne aktarımı hususunda aynı strateji izlenmiştir. İki çeviride de, kaynak metnin birbirinden farklı heteroglot sesleri ölçünlü dile aktarılmıştır. Bu durumun nedenini heteroglossia çevirisinin zor ya da imkânsız oluşuna bağlamak yanlış olur çünkü, farklı bağlamlarda örneklerini gördüğümüz gibi, çevirmenler zihinlerinde oluşturdukları belirli kitle tasarımları doğrultusunda çeviri yapmakta ve kaynak metnin heteroglot biçemini gerek gerçek erek dil değişkeleri yoluyla gerekse biçemsel düzeyde ürettikleri/uydurdukları bazı ortografik unsurlara dayanarak erek metin bağlamında yeniden oluşturmaktadır.

Yeniden çevirinin amaçlarından biri kaynak metnin daha önce yapılmış çevirisini biçemsel açıdan yenilemek ya da erek metnin biçemini kaynak metnin biçemsel özelliklerine yaklaştırmaktır (Koskinen \& Paloposki, 2003, s. 24). Ancak, Trainspotting'in 
yeniden çevirisinin heteroglot biçemin erek metinde oluşturulması amacını taşımadığını görmekteyiz. Bu bağlamda, her iki çevirinin de ölçünlü dil kullanması ve Türk toplumunda düzgün, güzel ve doğru dil kullanımı ile ilgili olarak oluşturulan söylemler, her iki çevirmenin de zihninde var olan kitle tasarımı hakkında belirli ipuçları vermektedir. Bu ipuçları çerçevesinde, Trainspotting gibi kült bir eserin çevirisini başarıyla gerçekleştirmiş olan iki ayrı çevirmenin, özellikle kültürel unsurların aktarımı konusunda gösterdikleri başarı göz önünde bulundurulduğunda, heteroglot sesleri sistematik bir şekilde ölçünlü dile aktarmasının altında yatan sebebin büyük bir bölümünün çeviri geleneğimizde heteroglot biçeme çok fazla yer verilmemesi, özgün yazın metinlerimizde bile Trainspotting'in oluşturduğu düzeyde bir 'dil içi şiddet[in]' görülmemesi, söylemlerimizin genellikle güzel ve düzgün bir dil kullanımını teşvik etmesi olduğu sonucuna varılabilir. 


\section{Kaynakça}

Anderson, B. (1983). Imagined communities: reflections on the origin and spread of nationalism. Londra: Verso.

Apter, E. (2006). The translation zone. Princeton ve Oxford: Princeton University Press.

Bakhtin, M. M. (1981). The dialogic imagination. C. Emerson (trans.) ve M. Holmquist (Ed.). Austin: Texas UP.

Bakhtin, M. (2001). Unitary language. L. Burke, T. Crowley \& A. Girvin (Ed.), The Routledge Language and Cultural Theory Reader (ss. 269-279). Londra ve New York: Routledge.

Bell, A. (1984). Language style as audience design, Language in Society, 13(2), 145-204.

Boase-Beier, J. (2004). Saying what someone else meant: Style, relevance and translation. International Journal of Applied Linguistics, 14(2), 276-287.

Bourdieu, P. (1991). Language and symbolic power. J. B. Thompson (Ed.), and G. Raymond \& M. Adamson (Çev.). Cambridge: Polity in association with Basil Blackwell.

Cameron, D. (1995). Verbal hygiene. Londra: Routledge.

Chatman, R. (1990). Coming to terms: The rhetoric of narrative in fiction and film. Ithaca, N.Y.: Cornell University Press.

Clark, B. (1996). Stylistic analysis and relevance theory. Language and Literature, 5(3), 163-178.

Corbett, J. (1999). Written in the language of the Scottish nation: A history of literary translation into Scots. Clevedon: Multilingual Matters.

Craig, C. (1988). The history of Scottish literature (Vol. 4). Aberdeen: Aberdeen UP.

Craig, C. (2006). Devolving the Scottish novel. J. English (Ed.), A Concise Companion to Contemporary British Fiction (ss. 121-140). Oxford ve Malden, MA: Blackwell.

Cronin, M. (2003). Translation and globalization. Londra: Routledge.

Doğançay-Aktuna, S. (2004). Language planning in Turkey: Yesterday and today. International Journal of the Sociology of Language, 165, 5-32.

Erkazancl, H. (2006). Heteroglossia in Turkish translations: Locating the style of literary translation in an audience-design perspective. Yayımlanmamış doktora tezi. University of East Anglia, Norwich, Great Britain.

Faulkner, W. (1940). The Hamlet. New York: Random House.

Gal, S. (1998). Multiplicity and contention among language ideologies: A commentary. B. B. Schieffelin, K. A. Woolard \& P. V. Kroskrity (Ed.), Language Ideologies: Practice and Theory (ss.317-332). Oxford: Oxford University Press.

Gökpek, A. (2006). "Trainspotting çevirisi üzerine", http://www.izedebiyat.com/yazi.asp?id=20861, 12.04.2006 tarihinde erişildi.

Grice, H. P. (1975). Logic and conversation. A. P. Martinich (Ed.), The Philosophy of Language (ss. 159-70). Oxford: Oxford University Press.

Gumperz, J. J. (1982). Discourse strategies. Cambridge: Cambridge University Press. 
Gutt, E. A. (1991). Translation and relevance: Cognition and context. Oxford: Blackwell.

Gutt, E. A. (1998). "Textual properties, communicative clues, and the translator", http://cogprints.org/2584/01/TextualPropertiesCommunicativeClues.htm, $\quad 03.02 .2005$ tarihinde erişildi.

Gutt, E. A. (2000). Translation and relevance: Cognition and context (ikinci ve gözden geçirilmiş baskı). Manchester: St Jerome Publishing.

Hepçilingirler, F. (1999). Dedim "Ahh": Türkçe "Off" - 2. İstanbul: Remzi Kitabevi.

Kennedy, A.L. "Scots to death". The New York Times, 20 Temmuz 1996, s. 19.

Kongar, E. (2003). Yozlaşan medya ve yozlaşan Türkçe. İstanbul: Remzi Kitabevi.

Koskinen, K. \& Paloposki, O. (2003). Retranslations in the age of digital reproduction, Cadernos de Tradução, 1(11), 19-38.

Lane-Mercier, G. (1995). Towards a rhetorical practice of mimesis: Writing/reading/ (re)translating fictional sociolects. Recherches Semiotiques/Semiotic Inquiry, 15, (3), 105128.

MacKenzie, I. (2002). Paradigms of reading: Relevance theory and deconstruction. Basingstoke: Palgrave.

March, C. L. (2002). Rewriting Scotland: Welsh, McLean, Warner, Banks, Galloway, and Kennedy. Manchester: Manchester University Press.

Myers, G. (1989). The pragmatics of politeness in scientific articles, Applied Linguistics, 10(1), 135.

Nord, C. (1997). Translating as a purposeful activity. Functionalist Approaches Explained. Manchester: St. Jerome.

Osborne, C. (1996). "Welsh accuses the middle classes of cultural bias." the Sunday Telegraph, 30 Mart 1996.

Özel, S. (2000). Dil Kiri El Kiri. İstanbul: Bilgi Yayınevi.

Paker, S. (1986). Translated European literature in the late Ottoman literary polysystem, New Comparison, 1, 67-79.

Poe, E. A. ([1843] 1994). The Gold Bug. Selected tales. London: Penguin.

Poe, E. A. (1974). Altın Böcek. Kızıl Ölümün Maskesi (T. Uyar, Çev.). İstanbul: Nisan Yayıncılık.

Seyhan, A. (2005). German academic exiles in İstanbul: Translation as the Bildung of the Other. S. Bermann \& M. Wood (Ed.), Nation, Language, and the Ethics of Translation (ss. 274-288). Princeton ve Oxford: Princeton University Press.

Sperber, D. and Wilson, D. (1990). Rhetoric and relevance. J. Bender \& D. Wellbery (Ed.) The Ends of Rhetoric (ss. 140-155). Stanford UP: Palo Alto.

Sperber, D. and Wilson D. ([1986]1995). Relevance: Communication and cognition. Oxford: Blackwell.

Suominen,

M.

(2001).

"Heteroglot

Soldiers", http://www.eng.helsinki.fi/hes/Translation/heteroglot_soldiers1.htm, tarihinde erişildi. 
Talib, I. S. (2002). The language of postcolonial literatures. An Introduction. Londra ve New York: Routledge.

Thomson, C. (2004). Slainte, I goes, and he says his word: Morvern Callar undergoes the trial of the foreign. Language and Literature, 13(1), 55-71.

Venuti, L. (1998). The scandals of rranslation: Towards an ethics of difference. Londra ve New York: Routledge.

Welsh, I. (1994). Trainspotting. London: Minerva.

Welsh, I. (2001). Trainspotting (S. Kaliç, Çev.). İstanbul: Stüdyo İmge.

Welsh, I. (2010). Trainspotting (A. Pardo, Çev.). Istanbul: Siren Yayınları.

Yağcıoglu, S. (2004). Book review. International Journal of the Sociology of Language, 165, 183186. 